\title{
Short communication: Combined antimicrobial activity of reuterin and diacetyl against foodborne pathogens
}

\author{
S. Langa, ${ }^{1}$ I. Martín-Cabrejas, R. Montiel, J. M. Landete, M. Medina, and J. L. Arqués \\ Dpto. de Tecnología de Alimentos, Instituto Nacional de Investigación y Tecnología Agraria y Alimentaria (INIA), Carretera de La Coruña Km 7 , \\ 28040 Madrid, Spain
}

\section{ABSTRACT}

Reuterin ( $\beta$-hydroxypropionialdehyde) is a broadspectrum antimicrobial substance produced by some strains of Lactobacillus reuteri during anaerobic fermentation of glycerol. Some of these strains are able to survive and produce reuterin in cheese and yogurt when added as adjuncts to the starter. Similarly, in fermented dairy foods, other inhibitory compounds such as lactic acid and diacetyl are produced during fermentation. In this work, we studied the combined effect of reuterin and diacetyl under different $\mathrm{pH}$ conditions against Escherichia coli O157:H7, Salmonella Enteritidis, and Listeria monocytogenes. Results from agar spot assays showed that the antimicrobial activity of reuterin-producing strains against the gram-negative bacteria tested was enhanced as the concentration of diacetyl increased to $50 \mathrm{mg} / \mathrm{kg}$, and was higher under acidic conditions ( $\mathrm{pH}$ 5.0) for the 3 pathogenic strains. The combination of reuterin and diacetyl had an additive effect against $L$. monocytogenes only at diacetyl concentrations of $50 \mathrm{mg} / \mathrm{kg}$ and $\mathrm{pH} 5.0$. In addition, growth kinetics studies showed that the combination of 1 activity unit (AU)/mL of reuterin with $100 \mathrm{mg} /$ $\mathrm{kg}$ diacetyl increased the lag time of the 3 pathogens. In milk, synergistic antimicrobial activity was observed with the combination of $1 \mathrm{AU} / \mathrm{mL}$ reuterin and 50 or $100 \mathrm{mg} / \mathrm{kg}$ of diacetyl on the gram-negative strains tested, and with $1 \mathrm{AU} / \mathrm{mL}$ reuterin and $100 \mathrm{mg} / \mathrm{kg}$ of diacetyl on $L$. monocytogenes. The greatest inhibition of the 3 pathogens was achieved in acidified milk at $\mathrm{pH}$ 5.0 with reuterin $(1 \mathrm{AU} / \mathrm{mL})$ and diacetyl $(100 \mathrm{mg} / \mathrm{kg})$. Based on these results, the combination of reuterin and diacetyl in acidified dairy products could be a promising strategy to control food pathogens in these products.

Key words: reuterin, diacetyl, bioprotection, foodborne pathogen

Received April 30, 2014.

Accepted June 14, 2014.

${ }^{1}$ Corresponding author: langa.susana@inia.es

\section{Short Communication}

Reuterin ( $\beta$-hydroxypropionialdehyde; $\beta$-HPA) is a broad-spectrum antimicrobial substance produced by some strains of Lactobacillus reuteri during anaerobic fermentation of glycerol, which shows activity against foodborne pathogens and spoilage microorganisms (Axelson et al., 1989). The use of reuterin to control gram-positive and gram-negative foodborne pathogens has been previously investigated in milk and dairy products (el-Ziney and Debevere, 1998; Arqués et al., 2008a,b). Interestingly, reuterin is soluble in water and resistant to heat and proteolytic and lipolytic enzymes, and it maintains its antimicrobial activity at low $\mathrm{pH}$ and high $\mathrm{NaCl}$ concentrations (Rasch, 2002; Rasch et al., 2007). Diacetyl (2,3-butanodione) is a volatile compound produced during cheese ripening and yogurt production by different citrate-utilizing lactic acid bacteria (LAB) strains (Hugenholtz, 1993). It is responsible for the typical flavor of butter and some cheese varieties and is often used as a flavoring compound of many food products, being considered a generally recognized as safe (GRAS) food ingredient (Jay, 1982). The antimicrobial activity of diacetyl against foodborne pathogens has been previously described (Jay, 1982; Kang and Fung, 1999). Escherichia coli O157:H7, Salmonella spp., and Listeria monocytogenes are pathogens of major concern to the food industry. Combinations of reuterin or diacetyl with other antimicrobials have shown a synergistic antimicrobial effect against foodborne pathogens (Arqués et al., 2008b, 2011; O'Bryan et al., 2009).

In practical terms, the addition of combinations of different preservatives in small amounts (hurdle technology) is often more effective than the use of only preservative in higher amounts, because different preservatives may act synergistically. The combined antimicrobial activity of reuterin and diacetyl, 2 biopreservatives that can be produced in situ in dairy products by LAB used as starters or adjunct cultures, has never been studied. Hence, the aim of this work was to evaluate the antimicrobial activity of different combinations of reuterin and diacetyl at different $\mathrm{pH}$ 
conditions against E. coli O157:H7, Salmonella Enteritidis, and L. monocytogenes.

Reuterin-producing (Lactobacillus reuteri INIA P569, INIA P570, INIA P572, INIA P577, and INIA P579) and nonproducing $(L b$. reuteri INIA P581, INIA P582, and INIA P583) strains were selected from the Instituto Nacional de Investigación y Tecnología Agraria y Alimentaria (INIA) culture collection (Madrid, Spain). All $L b$. reuteri strains were grown as previously described (Langa et al., 2013). Escherichia coli K12 CECT 433, E. coli O157:H7 CECT 4972, Salmonella enterica ssp. enterica serovar Enteritidis CECT 4300 from the Spanish Type Culture Collection (Valencia, Spain) and Listeria monocytogenes OHIO serotype 4b (from R. G. Crawford, Food and Drug Administration, Cincinnati, $\mathrm{OH}$ ), were grown in tryptic soy broth (Biolife s.r.l., Milan, Italy). Reuterin was purified and determined as described in Montiel et al. (2014).

The reuterin antimicrobial activity assay was a modification of the agar spot method described by Spinler et al. (2008). Two-microliter spots of Lb. reuteri strains were grown for $18 \mathrm{~h}$ at $37^{\circ} \mathrm{C}$ under anaerobic conditions and then overlaid with $0.7 \%$ brain-heart infusion agar with $20 \mathrm{~m} M$ glucose, $50 \mathrm{~m} M$ glycerol, and $6 \log \mathrm{cfu} / \mathrm{mL}$ of the pathogenic strain. Different diacetyl concentrations (0-100 mg/kg; Sigma-Aldrich, St Louis, MO) and $\mathrm{pH}$ reduction to 5.0 with lactic acid were also tested with $L b$. reuteri INIA P572 and INIA P579. Plates were incubated at $37^{\circ} \mathrm{C}$ for $3 \mathrm{~h}$ under anaerobic conditions and, then, under aerobic conditions for up to $24 \mathrm{~h}$. Plates without glycerol or with non-reuterin-producing Lb. reuteri strains were used as negative controls. Inhibition curves were performed in microtiter plates with $200 \mu \mathrm{L}$ of tryptic soy broth containing $6 \log \mathrm{cfu} / \mathrm{mL}$ of the pathogenic strain, different combinations of purified reuterin $[0,1$, and 2 activity units $(\mathbf{A U}) / \mathrm{mL}]$, and diacetyl $(0-100 \mathrm{mg} / \mathrm{kg})$. The kinetic parameters maximum growth rate $\left(\boldsymbol{\mu}\right.$; expressed in $\left.\mathrm{h}^{-1}\right)$ and lag time $(\boldsymbol{\lambda}$, expressed in h) were studied as in Montiel et al. (2014). Pathogenic strains were inoculated individually at approximately $3 \log \mathrm{cfu} / \mathrm{mL}$ in reconstituted skim milk supplemented with different concentrations of purified reuterin $(0,1$, or $2 \mathrm{AU} / \mathrm{mL})$ and diacetyl $(0-250 \mathrm{mg} /$ $\mathrm{kg}$ ). When necessary, normal milk $\mathrm{pH}$ (approximately 6.6) was adjusted to 5.0 with $10 \%$ lactic acid. Milk was kept at $37^{\circ} \mathrm{C}$ and counts of E. coli, Salmonella Enteritidis, and L. monocytogenes were determined on duplicate plates of tryptic soy agar. Two separate experiments were carried out. Data were subjected to ANOVA using the SPSS program 12.0 for Windows (SPSS Inc., Chicago, IL). Significant differences were assessed by Tukey's test at $P<0.01$ using the same program.
Results from agar spot assays indicated that all reuterin-producing $L b$. reuteri strains tested were able to inhibit the 3 pathogenic strains. No inhibition was observed in plates that did not contain glycerol or that had the non-reuterin-producing strains (data not shown). Strains $L b$. reuteri INIA P572 and INIA P579 were selected for additional assays because of their higher reuterin production. The results at $\mathrm{pH} 7.0$ and 5.0 and with different diacetyl concentrations are shown in Figure 1. Results indicated that, at $\mathrm{pH}$ 7.0, the zones of inhibition produced by reuterin-producing $L b$. reuteri colonies in plates inoculated with 2 gramnegative strains enlarged as the concentration of diacetyl increased. However, in the case of L. monocytogenes, no increase in the inhibition zones was observed in the presence of any diacetyl concentration tested. The zones of inhibition were larger at $\mathrm{pH} 5.0$ for the 3 pathogenic strains. This increase was particularly marked in the case of $E$. coli $\mathrm{O} 157: \mathrm{H} 7$ as inhibition zones increased drastically compared with those at $\mathrm{pH} 7.0$ at all diacetyl concentrations. The combination of $50 \mathrm{mg} / \mathrm{kg}$ of diacetyl and $\mathrm{pH} 5.0$ resulted in the highest inhibitory activity of the 2 reuterin-producing $L b$. reuteri strains against the 3 pathogens (Figure 1). Previously, el-Ziney et al. (1999) showed that lactic acid enhances the efficacy of reuterin as an antimicrobial.

The reuterin purified stock was used for inhibition curve experiments at 1 and $2 \mathrm{AU} / \mathrm{mL}$ reuterin, which correspond to 2.5 and $5.1 \mathrm{mM}$, respectively. Reuterin at $1 \mathrm{AU} / \mathrm{mL}$ was not enough to completely inhibit the growth of pathogens. However, this treatment significantly increased $(P<0.01)$ lag time in the 3 pathogens. Its combination with $100 \mathrm{mg} / \mathrm{kg}$ diacetyl significantly increased $(P<0.01)$ lag time in all strains compared with $1 \mathrm{AU} / \mathrm{mL}$ reuterin alone, although the increase was higher against the gram-negative strains. Maximum growth rate was significantly reduced $(P<$ 0.01 ) by the combination of $1 \mathrm{AU} / \mathrm{mL}$ reuterin and 100 $\mathrm{mg} / \mathrm{kg}$ of diacetyl only in E. coli O157:H7. Diacetyl treatment alone at $100 \mathrm{mg} / \mathrm{kg}$ was able to significantly inhibit $(P<0.01)$ the maximum growth rate of $E$. coli, whereas growth rates of Salmonella Enteritidis or Listeria were not influenced by any of the diacetyl concentrations tested. However, for Listeria, we did observe a significant increase in the lag time when the diacetyl concentration reached $100 \mathrm{mg} / \mathrm{kg}$ (Table 1). Addition of $2 \mathrm{AU} / \mathrm{mL}$ reuterin was enough to inhibit completely E. coli O157:H7 and Salmonella Enteritidis growth during the first $24 \mathrm{~h}$, whereas some bacterial growth was detected after $20 \mathrm{~h}$ for L. monocytogenes. The combination of $2 \mathrm{AU} / \mathrm{mL}$ reuterin with diacetyl did not enhance the antimicrobial effect observed for reuterin in L. monocytogenes. 


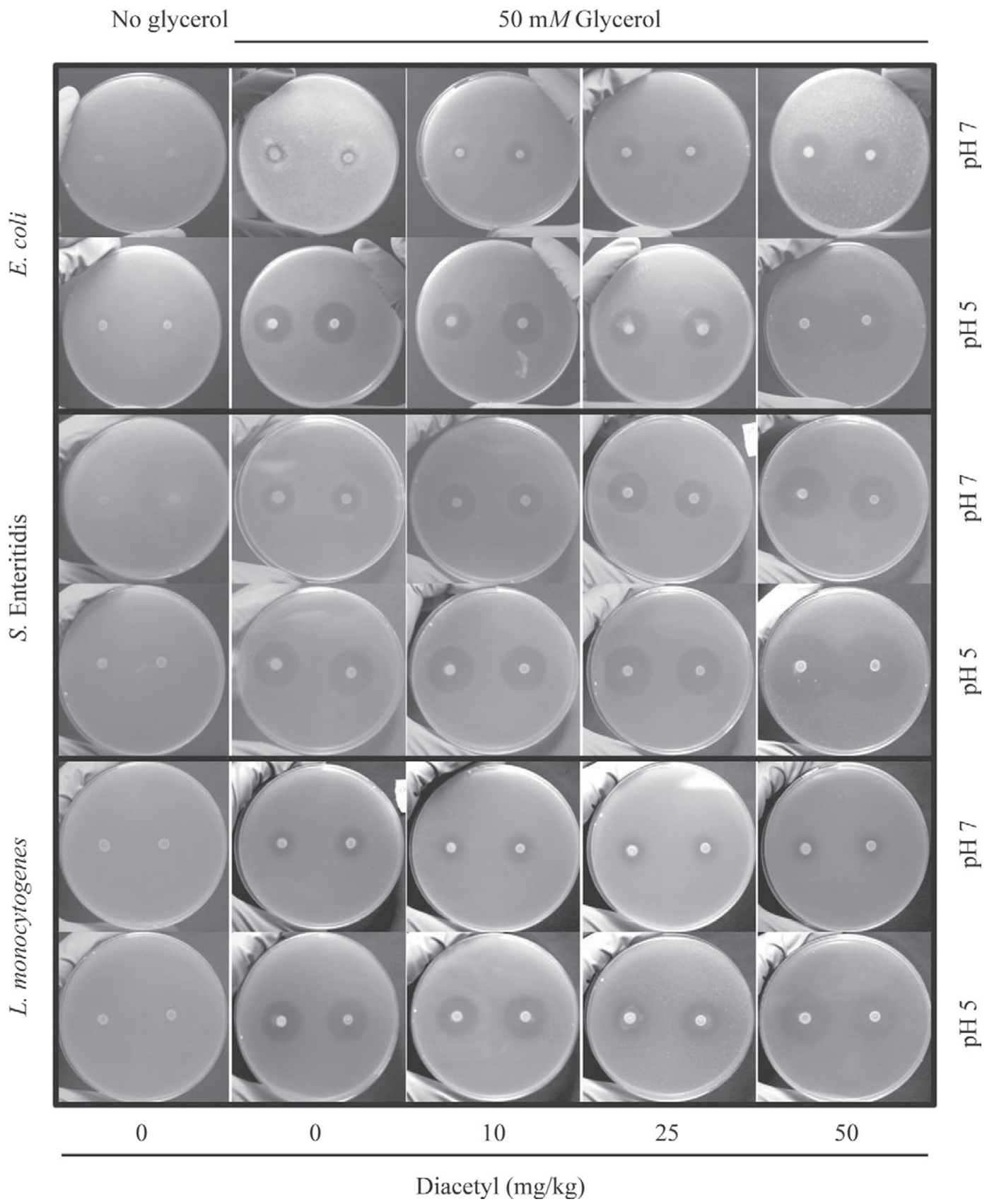

Figure 1. Inhibitory activity of Lactobacillus reuteri INIA P572 (left dot) and INIA P579 (right dot) on the growth of Escherichia coli O157:H7, Salmonella Enteritidis, and Listeria monocytogenes. Assays were performed on agar plates containing $50 \mathrm{~m} M$ glycerol at different diacetyl concentrations $(0-50 \mathrm{mg} / \mathrm{kg})$ and $\mathrm{pH}$ conditions (7.0 and 5.0). Plates without glycerol were used as negative controls.

Counts of the 3 pathogenic strains tested in milk were significantly $(P<0.001)$ influenced by reuterin, diacetyl, and $\mathrm{pH}$ treatments, their combination, and incubation time $(P<0.001)$, according to ANOVA results. Results in Table 2 showed that, at normal milk pH, the counts of E. coli O157:H7, Salmonella Enteritidis, and $L$. monocytogenes were significantly $(P<$ 0.01 ) influenced by diacetyl only at $250 \mathrm{mg} / \mathrm{kg}$, with counts $7.11,2.54$, and $3.80 \log$ units lower than those in control milk, respectively, after $24 \mathrm{~h}$. After $6 \mathrm{~h}$, reuterin had a bacteriostatic effect on E. coli and Salmonella Enteritidis, because the initial bacterial levels did not decrease, whereas reuterin led to $L$. monocytogenes counts $0.43 \mathrm{log}$ units lower than in control milk. After $24 \mathrm{~h}$, growth resumed in all cases and E. coli O157:H7, Salmonella Enteritidis, and L. monocytogenes reached 
Table 1. Estimated maximum growth rate $(\mu)$ and lag time $(\lambda)$ of Escherichia coli O157:H7, Salmonella Enteritidis, and Listeria monocytogenes in the presence of different combinations of reuterin (activity units, $\mathrm{AU})$ and diacetyl

\begin{tabular}{|c|c|c|c|c|c|}
\hline \multirow[b]{2}{*}{ Strain } & \multirow[b]{2}{*}{ Parameter } & \multirow{2}{*}{$\begin{array}{l}\text { Diacetyl } \\
\text { (mg/kg) }\end{array}$} & \multicolumn{3}{|c|}{ Reuterin $(\mathrm{AU} / \mathrm{mL})$} \\
\hline & & & 0 & 1 & 2 \\
\hline \multirow[t]{10}{*}{ E. coli } & $\mu\left(\mathrm{h}^{-1}\right)$ & 0 & $0.171^{\mathrm{ab}}$ & $0.137^{\mathrm{b}}$ & $0.000^{\mathrm{d}}$ \\
\hline & & 10 & $0.164^{\mathrm{ab}}$ & $0.140^{\mathrm{b}}$ & $0.000^{\mathrm{d}}$ \\
\hline & & 25 & $0.187^{\mathrm{a}}$ & $0.142^{\mathrm{b}}$ & $0.000^{\mathrm{d}}$ \\
\hline & & 50 & $0.126^{\mathrm{b}}$ & $0.145^{\mathrm{b}}$ & $0.000^{\mathrm{d}}$ \\
\hline & & 100 & $0.070^{\mathrm{c}}$ & $0.064^{\mathrm{c}}$ & $0.000^{\mathrm{d}}$ \\
\hline & $\lambda(\mathrm{h})$ & 0 & $1.11^{\mathrm{a}}$ & $7.51^{\mathrm{b}}$ & - \\
\hline & & 10 & $1.73^{\mathrm{a}}$ & $9.60^{\mathrm{b}}$ & - \\
\hline & & 25 & $1.68^{\mathrm{a}}$ & $10.57^{\mathrm{b}}$ & - \\
\hline & & 50 & $1.35^{\mathrm{a}}$ & $9.50^{\mathrm{b}}$ & - \\
\hline & & 100 & $1.47^{\mathrm{a}}$ & $12.72^{\mathrm{c}}$ & - \\
\hline \multirow[t]{10}{*}{ Salmonella Enteritidis } & $\mu\left(\mathrm{h}^{-1}\right)$ & 0 & $0.110^{\mathrm{ab}}$ & $0.102^{\mathrm{ab}}$ & $0.000^{\mathrm{c}}$ \\
\hline & & 10 & $0.119^{\mathrm{ab}}$ & $0.055^{\mathrm{bc}}$ & $0.000^{c}$ \\
\hline & & 25 & $0.075^{\mathrm{b}}$ & $0.117^{\mathrm{ab}}$ & $0.000^{\mathrm{c}}$ \\
\hline & & 50 & $0.148^{\mathrm{a}}$ & $0.059^{\mathrm{bc}}$ & $0.000^{\mathrm{c}}$ \\
\hline & & 100 & $0.097^{\mathrm{ab}}$ & $0.090^{\mathrm{ab}}$ & $0.000^{\mathrm{c}}$ \\
\hline & $\lambda(\mathrm{h})$ & 0 & $1.74 \mathrm{a}$ & $12.01^{\mathrm{b}}$ & - \\
\hline & & 10 & $1.70 \mathrm{a}$ & $13.37^{\mathrm{b}}$ & - \\
\hline & & 25 & $1.99 \mathrm{a}$ & $14.10^{\mathrm{b}}$ & - \\
\hline & & 50 & $2.36 \mathrm{a}$ & $14.79^{\mathrm{b}}$ & - \\
\hline & & 100 & $4.43 \mathrm{a}$ & $19.38^{\mathrm{c}}$ & - \\
\hline \multirow[t]{10}{*}{ L. monocytogenes } & $\mu\left(\mathrm{h}^{-1}\right)$ & 0 & $0.147^{\mathrm{a}}$ & $0.116^{\mathrm{abc}}$ & $0.070^{\mathrm{d}}$ \\
\hline & & 10 & $0.114^{\text {abcd }}$ & $0.104^{\text {abcd }}$ & $0.002^{\mathrm{e}}$ \\
\hline & & 25 & $0.126^{\mathrm{ab}}$ & $0.093^{\text {bcd }}$ & $0.007^{\mathrm{e}}$ \\
\hline & & 50 & $0.117^{\mathrm{abc}}$ & $0.104^{\text {abcd }}$ & $0.003^{\mathrm{e}}$ \\
\hline & & 100 & $0.111^{\mathrm{abcd}}$ & $0.102^{\text {abcd }}$ & $0.077^{\mathrm{cd}}$ \\
\hline & $\lambda(\mathrm{h})$ & 0 & $5.17^{\mathrm{a}}$ & $7.60^{\mathrm{cd}}$ & $20.42^{f}$ \\
\hline & & 10 & $6.25^{\mathrm{abc}}$ & $7.93^{\mathrm{de}}$ & $21.69^{f}$ \\
\hline & & 25 & $5.92^{\mathrm{ab}}$ & $8.42^{\text {de }}$ & $21.67^{\mathrm{f}}$ \\
\hline & & 50 & $6.30^{\mathrm{abc}}$ & $8.19^{\mathrm{de}}$ & $20.63^{\mathrm{f}}$ \\
\hline & & 100 & $6.70^{\mathrm{bcd}}$ & $9.15^{\mathrm{e}}$ & $20.30^{\mathrm{f}}$ \\
\hline
\end{tabular}

${ }^{\mathrm{a}-\mathrm{f}}$ Means with different superscripts indicate significant differences $(P<0.01)$ within the same strain and parameter.

counts 1.46, 1.07, and $0.39 \log$ units lower than those of control milk, respectively. A synergistic antimicrobial activity was observed between diacetyl and reuterin on the 3 pathogens tested: the combined effect was greater than the sum of reductions obtained by diacetyl and reuterin individually. The combination of $1 \mathrm{AU} / \mathrm{mL}$ reuterin with 50 or $100 \mathrm{mg} / \mathrm{kg}$ of diacetyl synergistically decreased the counts of E. coli O157:H7 and Salmonella Enteritidis. For L. monocytogenes, synergistic activity was also detected in milk with $1 \mathrm{AU} / \mathrm{mL}$ reuterin in combination with $100 \mathrm{mg} / \mathrm{kg}$ diacetyl. When normal milk $\mathrm{pH}$ was adjusted to 5.0, an inhibitory effect was detected on L. monocytogenes after $24 \mathrm{~h}$, with levels $2.00 \log$ units lower than those in control milk. The combined effect of low $\mathrm{pH}$ and reuterin was bactericidal after $6 \mathrm{~h}$ in the pathogenic strains tested. After $24 \mathrm{~h}, E$. coli and Salmonella Enteritidis counts decreased to 1.68 and $0.45 \log \mathrm{cfu} / \mathrm{mL}$, respectively, whereas growth of $L$. monocytogenes restarted, with counts reaching $4.73 \mathrm{log}$ $\mathrm{cfu} / \mathrm{mL}$. No additive bactericidal effect was obtained in the presence of diacetyl at any concentration, except for counts of L. monocytogenes, which showed levels $1.12 \log$ units lower in acidified milk treated with reuterin and $100 \mathrm{mg} / \mathrm{kg}$ diacetyl compared with levels in acidified milk with only reuterin.

These results are in concordance with previous studies that have shown a higher antimicrobial activity of reuterin or diacetyl on gram-negative than on grampositive pathogenic bacteria (Jay, 1982; Arqués et al., 2011; Stevens et al., 2011). The higher rate of inhibition observed for reuterin in combination with diacetyl, low $\mathrm{pH}$, or both, is an interesting feature because many dairy foods have a low $\mathrm{pH}$ due to the formation of lactic acid or diacetyl production during fermentation. A pH of 5.0 or less is common in many cheese varieties and fermented milks, and antimicrobial activity of diacetyl at concentrations ranging between 300 and $10,000 \mathrm{mg} /$ $\mathrm{kg}$ against E. coli, Salmonella, and L. monocytogenes has been reported (Jay, 1982; Olasupo et al., 2003; O'Bryan et al., 2009). Here, we were able to detect antimicrobial activity at diacetyl concentrations of 250 $\mathrm{mg} / \mathrm{kg}$, and this concentration could be reduced to 100 
Table 2. Counts (log cfu/mL) of Escherichia coli O157:H7, Salmonella Enteritidis, and Listeria monocytogenes in milk without biopreservatives $(-)$ or containing $1 \mathrm{AU}$ (activity units) $/ \mathrm{mL}$ reuterin in combination with different diacetyl concentrations $(\mathrm{mg} / \mathrm{kg}$ ) at normal milk $\mathrm{pH}$ or acidified to $\mathrm{pH} 5.0$ after 6 and $24 \mathrm{~h}$ incubation at $37^{\circ} \mathrm{C}$

\begin{tabular}{|c|c|c|c|c|c|c|c|c|}
\hline \multirow[b]{2}{*}{$\mathrm{pH}$} & \multirow[b]{2}{*}{ Reuteurin } & \multirow[b]{2}{*}{ Diacetyl } & \multicolumn{2}{|c|}{ E. coli } & \multicolumn{2}{|c|}{ Salmonella Enteritidis } & \multicolumn{2}{|c|}{ L. monocytogenes } \\
\hline & & & $6 \mathrm{~h}$ & $24 \mathrm{~h}$ & $6 \mathrm{~h}$ & $24 \mathrm{~h}$ & $6 \mathrm{~h}$ & $24 \mathrm{~h}$ \\
\hline \multirow[t]{11}{*}{ Normal milk pH } & - & 0 & $6.36^{\mathrm{a}}$ & $8.90^{\mathrm{a}}$ & $6.01^{\mathrm{a}}$ & $8.77^{\mathrm{ab}}$ & $5.30^{\mathrm{a}}$ & $7.95^{\mathrm{a}}$ \\
\hline & - & 10 & $6.20^{\mathrm{ab}}$ & $8.89^{\mathrm{a}}$ & $5.94^{\mathrm{a}}$ & $8.80^{\mathrm{a}}$ & $5.18^{\mathrm{ab}}$ & $7.90^{\mathrm{a}}$ \\
\hline & - & 25 & $6.03^{\mathrm{ab}}$ & $8.89^{\mathrm{a}}$ & $5.94^{\mathrm{a}}$ & $8.86^{\mathrm{a}}$ & $5.13^{\mathrm{ab}}$ & $7.79^{\mathrm{ab}}$ \\
\hline & - & 50 & $5.64^{\mathrm{abc}}$ & $8.88^{\mathrm{a}}$ & $5.54^{\mathrm{a}}$ & $8.75^{\mathrm{ab}}$ & $4.94^{\mathrm{abc}}$ & $7.79^{\mathrm{ab}}$ \\
\hline & - & 100 & $4.59^{\mathrm{abcd}}$ & $8.82^{\mathrm{a}}$ & $4.85^{\mathrm{ab}}$ & $8.79^{\mathrm{a}}$ & $4.09^{\mathrm{c}}$ & $7.56^{\mathrm{abc}}$ \\
\hline & - & 250 & $2.19^{\mathrm{g}}$ & $1.79^{\mathrm{d}}$ & $3.16^{\mathrm{bc}}$ & $6.23^{\mathrm{de}}$ & $2.85^{\mathrm{d}}$ & $4.15^{\mathrm{ef}}$ \\
\hline & + & 0 & $3.41^{\text {defg }}$ & $7.44^{\mathrm{a}}$ & $3.11^{\mathrm{bc}}$ & $7.70^{\mathrm{abc}}$ & $4.87^{\mathrm{abc}}$ & $7.56^{\mathrm{abc}}$ \\
\hline & + & 10 & $3.56^{\text {defg }}$ & $7.59^{\mathrm{a}}$ & $3.16^{\mathrm{bc}}$ & $7.91^{\mathrm{abc}}$ & $4.66^{\mathrm{abc}}$ & $7.49^{\mathrm{abc}}$ \\
\hline & + & 25 & $3.39^{\text {defg }}$ & $7.23^{\mathrm{ab}}$ & $3.09^{b c}$ & $7.72^{\mathrm{abc}}$ & $4.59^{\mathrm{abc}}$ & $7.39^{\mathrm{abc}}$ \\
\hline & + & 50 & $3.27^{\text {defg }}$ & $6.67^{\mathrm{ab}}$ & $3.09^{b c}$ & $5.41^{\mathrm{ef}}$ & $4.33^{\mathrm{bc}}$ & $7.30^{\mathrm{abc}}$ \\
\hline & + & 100 & $3.15^{\text {defg }}$ & $4.71^{b c}$ & $2.93^{\text {bcd }}$ & $4.88^{\mathrm{f}}$ & $4.01^{\mathrm{c}}$ & $6.88^{\mathrm{abcd}}$ \\
\hline \multirow[t]{10}{*}{ Acidic (pH 5.0) } & - & 0 & $4.53^{\text {bcde }}$ & $8.22^{\mathrm{a}}$ & $1.50^{\mathrm{cd}}$ & $7.70^{\mathrm{abc}}$ & $2.68^{\mathrm{d}}$ & $5.95^{\text {bcde }}$ \\
\hline & - & 10 & $4.08^{\text {cdef }}$ & $8.07^{\mathrm{a}}$ & $2.03^{\mathrm{cd}}$ & $7.66^{\mathrm{abc}}$ & $2.63^{\mathrm{d}}$ & $5.95^{\text {bcde }}$ \\
\hline & - & 25 & $4.69^{\mathrm{abcd}}$ & $8.14^{\mathrm{a}}$ & $2.18^{\mathrm{cd}}$ & $7.75^{\mathrm{abc}}$ & $2.51^{\mathrm{d}}$ & $5.98^{\text {bcde }}$ \\
\hline & - & 50 & $4.46^{\text {bcde }}$ & $8.20^{\mathrm{a}}$ & $2.24^{\mathrm{cd}}$ & $7.42^{\text {bcd }}$ & $2.52^{\mathrm{d}}$ & $5.72^{\text {cdef }}$ \\
\hline & - & 100 & $3.76^{\text {defg }}$ & $7.50^{\mathrm{a}}$ & $1.78^{\mathrm{cd}}$ & $6.65^{\text {cde }}$ & $2.40^{\mathrm{d}}$ & $5.33^{\mathrm{def}}$ \\
\hline & + & 0 & $2.14^{\mathrm{g}}$ & $1.68^{\mathrm{d}}$ & $1.81^{\mathrm{cd}}$ & $0.45^{\mathrm{g}}$ & $2.29^{\mathrm{d}}$ & $4.73^{\mathrm{ef}}$ \\
\hline & + & 10 & $2.05^{\mathrm{g}}$ & $2.16^{\mathrm{cd}}$ & $0.85^{\mathrm{d}}$ & $0.70^{\mathrm{g}}$ & $2.32^{\mathrm{d}}$ & $4.98^{\mathrm{def}}$ \\
\hline & + & 25 & $2.25^{\mathrm{g}}$ & $2.07^{\mathrm{d}}$ & $0.70^{\mathrm{d}}$ & $0.69^{\mathrm{g}}$ & $2.55^{\mathrm{d}}$ & $5.16^{\mathrm{def}}$ \\
\hline & + & 50 & $2.70^{\mathrm{efg}}$ & $2.32^{\mathrm{cd}}$ & $0.70^{\mathrm{d}}$ & $0.50^{\mathrm{g}}$ & $2.47^{\mathrm{d}}$ & $4.91^{\mathrm{ef}}$ \\
\hline & + & 100 & $2.26^{\mathrm{fg}}$ & $1.95^{\mathrm{d}}$ & $0.70^{\mathrm{d}}$ & $0.35^{\mathrm{g}}$ & $2.29^{\mathrm{d}}$ & $3.61^{\mathrm{f}}$ \\
\hline
\end{tabular}

${ }^{\mathrm{a}-\mathrm{g}}$ Means with different superscripts within the same column indicate significant differences $(P<0.01)$.

$\mathrm{mg} / \mathrm{kg}$ when diacetyl was used in combination with $1 \mathrm{AU} / \mathrm{mL}$ reuterin. The combination of reuterin with diacetyl allows use of both preservatives at reduced amounts that could occur naturally in the food systems. Reuterin concentrations of 4 and $2 \mathrm{AU} / \mathrm{mL}$ have been produced in situ by $L b$. reuteri INIA P572 and INIA P579 in cheese and yogurt, respectively (Langa et al., 2013), whereas different diacetyl concentrations (between 0 and $4,500 \mathrm{mg} / \mathrm{kg}$ ) have been detected in different cheese varieties and other dairy products (Zeppa et al., 2001). Therefore, those reuterin-producing strains could be used in combination with diacetyl, as a food ingredient, or with diacetyl-producing Lactococcus lactis strains for continuous in situ production of both compounds in dairy products over time. The exact mechanism of the synergistic activity of these 2 compounds is not clear. Reuterin antimicrobial activity is mainly attributed to its ability to react with sulfhydryl groups of amino acids, triggering an oxidative stress response (Schaefer et al., 2010; Vollenweider et al., 2010), whereas the antimicrobial activity of diacetyl might be exerted by inactivating arginine utilization through its reaction with the arginine-binding protein (Jay, 2000). The combination of the 2 antimicrobials could prevent the development of resistance.

This work highlights the synergistic effect of reuterin and diacetyl, 2 natural antimicrobial compounds produced by LAB in acidified dairy products. Addition or in situ production of both antimicrobials by selected LAB added as adjuncts to the starter culture might be an interesting tool that could be exploited to control the growth of pathogens potentially present in dairy products.

\section{ACKNOWLEDGMENTS}

This work was supported by the projects RTA 201000116-00-00, AGL2010-16600, and RC2010-06925 from the Spanish Ministry of Economy and Competitiveness (Madrid, Spain).

\section{REFERENCES}

Arqués, J. L., E. Rodríguez, M. Nuñez, and M. Medina. 2008a. Inactivation of gram-negative pathogens in refrigerated milk by reuterin in combination with nisin or the lactoperoxidase system. Eur. Food Res. Technol. 227:77-82.

Arqués, J. L., E. Rodríguez, M. Nuñez, and M. Medina. 2008b. Antimicrobial activity of nisin, reuterin, and the lactoperoxidase system on Listeria monocytogenes and Staphylococcus aureus in cuajada, a semisolid dairy product manufactured in Spain. J. Dairy Sci. $91: 70-75$.

Arqués, J. L., E. Rodriguez, M. Nuñez, and M. Medina. 2011. Combined effect of reuterin and lactic acid bacteria bacteriocins on the inactivation of food-borne pathogens in milk. Food Contr. 22:457-461.

Axelson, T., T. C. Chung, W. J. Dobrogosz, and S. E. Lindgren. 1989. Production of a broad spectrum antimicrobial substance by Lactobacillus reuteri. Microb. Ecol. Health Dis. 2:131-136. 
el-Ziney, M. G., and J. M. Debevere. 1998. The effect of reuterin on Listeria monocytogenes and Escherichia coli O157:H7 in milk and cottage cheese. J. Food Prot. 61:1275-1280.

el-Ziney, M. G., T. van den Tempel, J. Debevere, and M. Jackobsen. 1999. Application of reuterin produced by Lactobacillus reuteri 12002 for meat decontamination and preservation. J. Food Prot. 62:257-261.

Hugenholtz, J. 1993. Citrate metabolism in lactic acid bacteria. FEMS Microbiol. Rev. 12:165-178.

Jay, J. M. 1982. Antimicrobial properties of diacetyl. Appl. Environ. Microbiol. 44:525-532.

Jay, J. M. 2000. Modern Food Microbiology. 6th ed. Van Nostrand Reinhold, New York, NY.

Kang, D. H., and D. Y. Fung. 1999. Effect of diacetyl on controlling Escherichia coli O157:H7 and Salmonella typhimurium in the presence of starter culture in a laboratory medium and during meat fermentation. J. Food Prot. 62:975-979.

Langa, S., J. M. Landete, I. Martín-Cabrejas, E. Rodríguez, J. L. Arqués, and M. Medina. 2013. In situ reuterin production by Lactobacillus reuteri in dairy products. Food Contr. 33:200-206.

Montiel, R., I. Martín-Cabrejas, S. Langa, N. El Aoad, J. L. Arqués, F. Reyes, and M. Medina. 2014. Antimicrobial activity of reuterin produced by Lactobacillus reuteri on Listeria monocytogenes in cold-smoked salmon. Food Microbiol. 44:1-5. http://dx.doi. org/10.1016/j.fm.2014.05.006.

O'Bryan, C. A., M. L. Sostrin, R. Nannapaneni, S. C. Ricke, P. G. Crandall, and M. G. Johnson. 2009. Sensitivity of Listeria monocytogenes Scott A to nisin and diacetyl after starvation in sodium phosphate buffered saline. J. Food Sci. 74:M493-498.

Olasupo, N. A., D. J. Fitzgerald, M. J. Gasson, and A. Narbad. 2003. Activity of natural antimicrobial compounds against Escherichia coli and Salmonella enterica serovar Typhimurium. Lett. Appl. Microbiol. 37:448-451.

Rasch, M. 2002. The influence of temperature, salt and $\mathrm{pH}$ on the inhibitory effect of reuterin on Escherichia coli. Int. J. Food Microbiol. 72:225-231.

Rasch, M., A. Métris, J. Baranyi, and B. Bjørn Budde. 2007. The effect of reuterin on the lag time of single cells of Listeria innocua grown on a solid agar surface at different $\mathrm{pH}$ and $\mathrm{NaCl}$ concentrations. Int. J. Food Microbiol. 113:35-40.

Schaefer, L., T. A. Auchtung, K. E. Hermans, D. Whitehead, B. Borhan, and R. A. Britton. 2010. The antimicrobial compound reuterin (3-hydroxypropionaldehyde) induces oxidative stress via interaction with thiol groups. Microbiology 156:1589-1599.

Spinler, J. K., M. Taeweechotipatr, C. L. Rognerud, C. N. Ou, S. Tumwasorn, and J. Versalovic. 2008. Human-derived probiotic Lactobacillus reuteri demonstrate antimicrobial activities targeting diverse enteric bacterial pathogens. Anaerobe 14:166-171.

Stevens, M., S. Vollenweider, and C. Lacroix. 2011. The potential of reuterin produced by Lactobacillus reuteri as a broad spectrum preservative in food. Pages 129-160 in Protective Cultures, Antimicrobial Metabolites and Bacteriophages for Food and Beverage Biopreservation. C. Lacroix, ed. Woodhead Publishing Ltd., Cambridge, UK.

Vollenweider, S., E. Evers, K. Zurbriggen, and C. Lacroix. 2010. Unraveling the hydroxypropionaldehide (HPA) system: An active antimicrobial agent against human pathogens. J. Agric. Food Chem. 58:10315-10322.

Zeppa, G., L. Conterno, and V. Gerbi. 2001. Determination of organic acids, sugars, diacetyl, and acetoin in cheese by high-performance liquid chromatography. J. Agric. Food Chem. 49:2722-2726. 